\title{
IMPROVING STUDENTS' ABILITY TO WRITE NARRATIVE TEXT BY USING GRAPHIC ORGANIZER
}

\author{
Resty Maya Sari \\ Wisma Yunita \\ Azwandi \\ University of Bengkulu \\ Email : resty_leader@yahoo.com
}

\begin{abstract}
This paper was aimed to explain whether using Graphic Organizer can improve students' ability in writing narrative text and factors that influence the improvement of students' ability at grade IX A of SMPN 22 Kota Bengkulu in the 2012/2013 academic year. The result of this research shows that using graphic organizer has successfully improved the students' ability in writing narrative text, the improvement was influenced by the used of interesting material chosen and teacher's participation toward the students.
\end{abstract}

Keywords: Writing Skill, Narrative Text, Graphic Organizer.

\section{INTRODUCTION}

Writing is one of the four skills that students of foreign or second language should acquire. Writing skills are specific abilities which help writers put their thoughts into words in a meaningful form and to mentally interact with the message (Gudschinsky,1973). Moreover, there were several ways which could be done to improve students' ability in writing narrative text. Such as; by using picture [movie] related to the story, using graphic organizer, retelling the famous legend story, and giving a short narrative story. However, graphic organizer was one of technique which helped the students to classify ideas and communicate more effectively. Use graphic organizers to structure writing projects, to help in problem solving, decision making, studying, planning, research and brainstorming. Some previous research was also proven that using graphic organizer has so many advantages. The similar research had been done by Delrose (2011), as the result, it proven that graphic organizer was effective to improve students' writing ability.

Moreover, Nichols (2005) suggests that the use of a graphic organizer before, during, and/or after the reading of a narrative text can help students learn the structure of the text. A graphic organizer is a visual representation of the structure of the text. In addition, a graphic organizer can be designed to help students recognize the structure of narrative text. Professional materials usually refer to this as developing a "sense of story" or "story grammar." Thus, this technique is used to help the students organize the structure of a narrative text then write it on a paper to be a piece of a good writing narrative text. Therefore, this 
current study was guided by two research questions:

1. To what extent was the improvement of students' ability in writing narrative text by using graphic organizer at grade IX, Class IX-A of SMPN 22 Kota Bengkulu?

2. What factors influenced the improvement of students' ability in writing narrative text at Grade IX, Class IX-A of SMPN 22 Kota Bengkulu?

\section{METHODS}

One of the educational research designs that used in this paper is classroom action research. Moreover the subject of this research was the student at grade IX A of SMPN 22 Kota Bengkulu in 2012/2013 academic year. There were 22 students in the classroom; nine (9) females and thirteen (13) males' students. According to Kemmis and McTaggart (1988) and Arikunto (2009, p. 70-71) classroom action research involves four phase in each cycles, they are planning, action, observation, and reflection. The instruments of this research were the students' and teacher's observation checklists, writing test, and interview. The data was collected in this paper is quantitative (students scores in evaluation test in each cycle) and qualitative (students' and teachers' observation checklist and interview) data.

\section{FINDINGS AND DISCUSSION}

Based on the data analysis above, the researcher found that the findings of this research have been answered the research questions as follows:

1. Graphic Organizer improved students' ability to write narrative text.

The chart below showed the improvement of students' score frequency in baseline data, cycle 1 , and cycle 2 :

Chart 1: The Students' Score in Writing Narrative Text in Baseline Data, Cycle 1, \&

Cycle 2

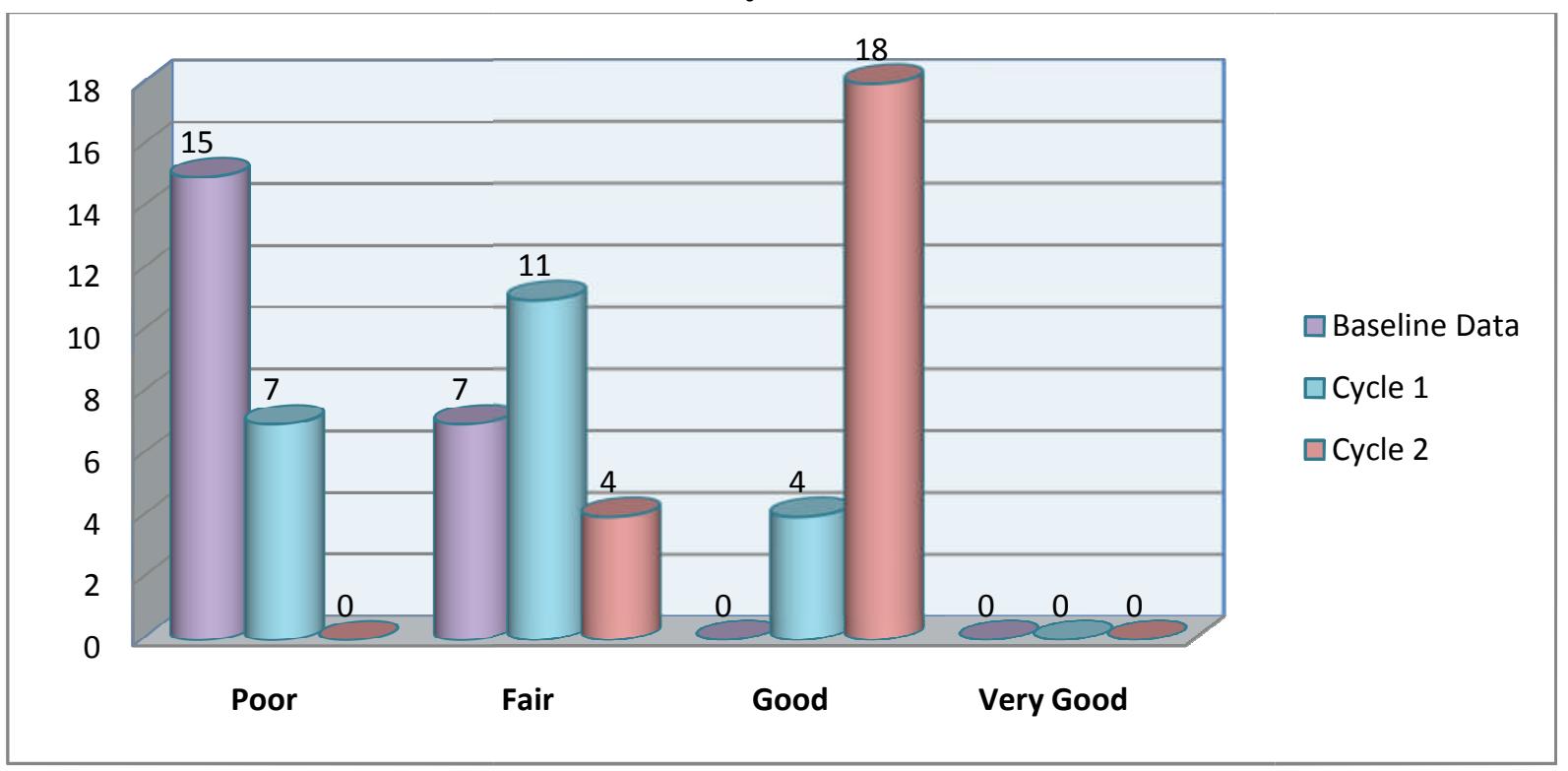


From the chart, it can be seen that there were significant improvement between the result in baseline data, cycle 1 , and cycle 2 .

Based on the test result, there were 15 or $68.18 \%$ and 7 or $31.81 \%$ of students who got poor category in baseline data and cycle 1 decreased into 0 or $0.00 \%$ student in cycle 2. Then, 7 or $31.81 \%$ and 11 or $5.00 \%$ of students who got fair category in baseline data and cycle 1 decreased into 4 or $18.18 \%$ of students in cycle 2 .

Furthermore, 0 or $0.00 \%$ and 4 or $18.18 \%$ of students who got good category in baseline data and cycle 1 increased in cycle 2 that there were 18 or $(81.81 \%)$ of students gained good score. To the next, there was no student who got very good category in baseline data, cycle 1 , and cycle 2. To sum up, the researcher concluded that the research should be ended in cycle 2 since the result of writing narrative test in cycle 2 was satisfied and could fulfill the indicator.

The improvement of students' writing ability was especially in analyzing 5 aspects of composition profile scoring guide, they were content, organization, vocabulary, language use, and mechanics aspects. Each aspect showed better improvement in every cycle. Furthermore, the improvement of each aspect will be illustrated in the chart below:

\section{Chart 2: The Improvement of Students' Mean Score of Scoring in Baseline Data, Cycle}

\section{1, \& Cycle 2}

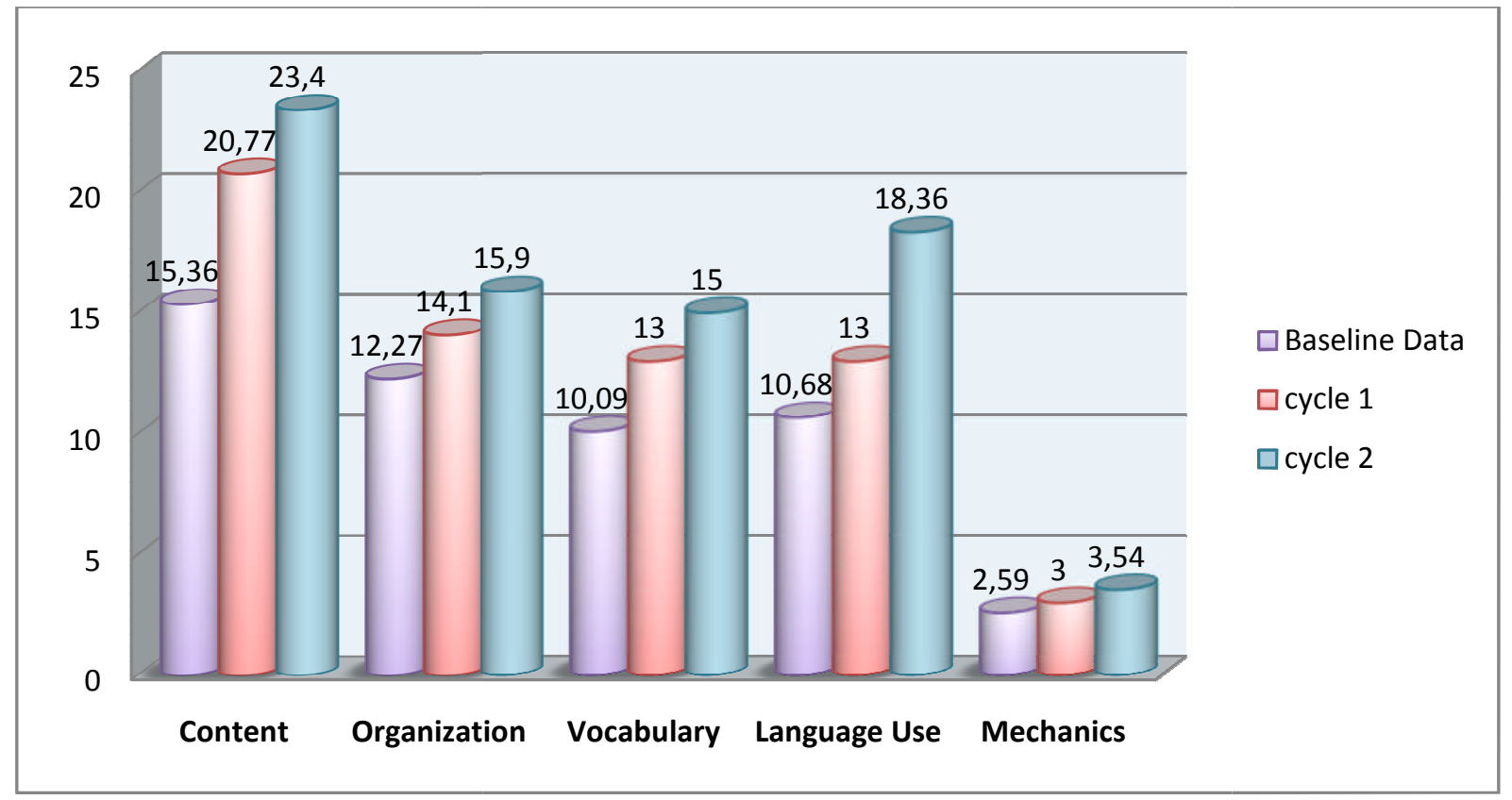

From the chart above, it could be seen that there were better improvements from the mean score of aspects scoring based on the composition profile scoring guide. Firstly, the mean score of content aspect in cycle 1 increased from 15.36 in baseline data and 20.77 in cycle 1 to 23.4 in cycle 2. Secondly, the mean score of organization aspect increased from 12.27 in baseline data and 14.1 in cycle 1 to 15.9 in cycle 2 . 
Thirdly, the mean score of vocabulary aspect increased from 10.09 in baseline data and 13 in cycle 1 to 15 in cycle 2 . Fourthly, the mean score of language use aspect increased from 10.68 in baseline data and 13 in cycle 1 to 18.36 in cycle 2 , and the last mean score of mechanics aspect increased from 2.59 in baseline data and 3 in cycle 1 to 3.54 in cycle 2 . Based on the result, the researcher concluded that there were significant improvements of each aspect.

Furthermore, the results of the observation checklist and field notes were satisfying and the research could be ended in this cycle. 2. The factors influencing the improvement of students' writing ability.

Besides having the result of the improvement on students' writing ability through writing tests which were held at the end of each cycle, the researcher also found that the improvement toward using of graphic organizer was influenced by two factors.

The first factor was the material chosen. Based on the observation checklist and field notes, it was found the atmosphere of teaching learning process through the implementation of graphic organizer by using some interesting texts was so authentic.

Interaction, attention, and respect among the students were good. Moreover, based on the observation checklist and field notes, it was showed that the students were looked enthusiast to use graphic organizer since it was their first time applied this kind of technique. They also were enthusiast to the text chosen for the learning material.
The texts chosen in cycle 2 were more interesting than cycle 1 .

The last factor was teachers' participation. Based on the observation checklists and field notes, students' attitude in cycle 2 was better than cycle 1 . It could be seen by the teachers' observation checklist in cycle 1 and cycle 2 .

The teacher's participation was consisted of the teacher's activities such as: the teacher delivered the material would be taught, the teacher explained the using graphic organizer, and the teacher taught writing narrative text by using graphic organizer. For the first activity, the teacher delivered the material in cycle 2 better and clearer than cycle 1 .

All of the students listened and gave respond. For the second activity, the teacher's explanation about using graphic organizer was better too, the teacher's explanation was clear; almost all of the students' gave positive enthusiast toward the teacher's explanation. For the last activity, the teachers' assisting and guiding students were the main activity that influenced the improvement of the students' writing narrative text.

The researcher concluded that the improvement of students' ability in writing narrative text was also influenced by teacher's participation.

However, based on the explanation above, the improvement of student' writing ability was not only caused by the material chosen, but also by the teacher's participation toward using graphic organizer. It was included teacher's explanation, assisting, and guiding the 
students. The teacher had an important role in improvement of students' writing narrative ability. To sum up, both of the material chosen and the teacher's participation became the factors influencing the improvement of students' writing ability.

The result of this research was compared to some theories and ideas explained in chapter 2 . The improvement of students' mean score in cycle 1 and cycle 2 was significant. The students' mean score in cycle 1 that 62.82 increased into 76.22 in cycle 2. It was also looked by the improvement of students' percentage category that 4 or $18.18 \%$ of students which got good category in cycle 1 increased into 18 or $81.81 \%$ of students in cycle 2 .

Based on the improvement of each cycles, using graphic organizer technique did improve students' writing narrative ability. The result of this research was also similar to the result of some previous studies. Firstly, the result of the research by Delrose (2011) was similar to the result of this research which also proven that using graphic organizer can be an effective tool be used in writing process, in generating narrative sentences which has more complex structure of syntax and discourse. Secondly, the result of the research by Gusweni (2011) also proven that graphic organizer has successfully improved students' reading comprehension and motivation, and trained students' to be active readers. Thirdly, the result of the research by Tsai and You (2009) proven that using graphic organizer in Elementary School can be a tool or strategy to motivate and facilitate the students to be creative in instructional activities.

Furthermore, the result of this research also confirms some theories and ideas from the experts. For the First, by using graphic organizer the students' academic achievement increased. This result was similar to the theory by Nichols (2005) which suggests that the use of graphic organizer can help students learn the structure of the text. It is used to help the students organize the structure of a narrative text then write it on a paper to be a piece of a good writing narrative text.

For the second, using graphic organizer improved students' ability in organizing the text. This result was supported by Morin (2010) which argues that graphic organizer is a series of visual charts and tools used to represent and organize students' knowledge or ideas. The increased students' academic achievements were proven from the significant mean score improvement between the organization aspect of scoring guide result in cycle 1 and cycle 2 .

For the last, using graphic organizer also improved the students' motivation. As similar as Nichols' (2005) theory which stated that graphic organizer is a kind of strategy that makes students be motivated and active. It can increase students' interesting in learning process.

\section{CONCLUSION}

The researcher concluded that using graphic organizer is effective to improve students' writing narrative text and also facilitate the students to be creative and being motivated 
especially at grade IX A of SMPN 22 Kota

Bengkulu 2012/2013 academic year.

\section{REFERENCES}

Abbot, Gerry.at al.1981. The Teaching of English as International Language: a Practical guide. Great Britain: Williams Collins sons and coLtd.

Anderson, Mark and Kathy Anderson. 1998. Text types in English 3. South Yarra: Macmillan Education AustraliaPTY LTD.

Arikunto, Suharsimi. (1998). Prosedur penelitian: suatu pendekatan praktek. Jakarta: Rienekacipta.

Delrose. (2011). Investigating the use of Graphic Organizers for writing". Published thesis University of Baltimore Law Review.
Gudchinsky. (1973). Teaching writing. New York: Oxford University Press.

Morin. (2010). Using graphic organizer in teaching English. Washington DC: Alliance Excellent for Education.

Nichols. (2005). The other side of the story: Using graphic organizer as cognitive learning tools to teach students to construct effective counteranalysis. Published thesis University of Baltimore Law Review.

Kemmis, S., \&McTaggart, R. (1988). The action research planner (3rd ed.).Victoria, Australia: Deakin University Press. 